\title{
Management of post-transplant Epstein-Barr virus-related lymphoproliferative disease in solid organ and hematopoietic stem cell recipients
}

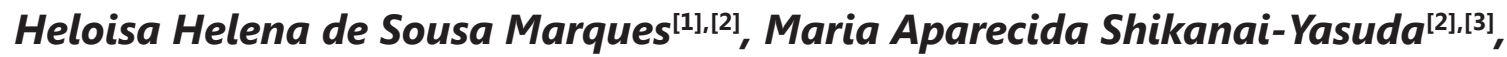 \\ Luiz Sérgio Fonseca de Azevedo ${ }^{[2],[4], ~ H e ́ l i o ~ H e l h ~ C a i a f f a-F i l h o ~}{ }^{[2],[5],}$

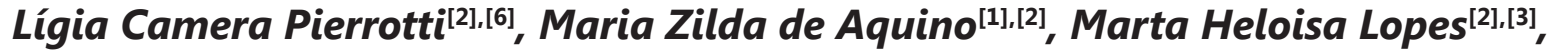 \\ Natalya Zaidan Maluf ${ }^{[2],[7]}$, Silvia Vidal Campos ${ }^{[2],[8]}$ and Silvia Figueiredo Costa ${ }^{[2],[3]}$
}

\begin{abstract}
[1]. Instituto da Criança, Hospital das Clínicas, Faculdade de Medicina, Universidade de São Paulo, São Paulo, SP. [2]. Comissão de Infecção em Imunodeprimidos, Hospital das Clínicas, Faculdade de Medicina, Universidade de São Paulo, São Paulo, SP. [3]. Departamento de Moléstias Infecciosas, Faculdade de Medicina, Universidade de São Paulo, São Paulo, SP. [4]. Serviço de Transplante Renal, Hospital das Clínicas, Faculdade de Medicina, Universidade de São Paulo, São Paulo, SP. [5]. Serviço de Biologia Molecular, Hospital das Clínicas, Faculdade de Medicina, Universidade de São Paulo, São Paulo, SP. [6]. Divisão de Moléstias Infecciosas, Hospital das Clínicas, Faculdade de Medicina, Universidade de São Paulo, São Paulo, SP. [7]. Serviço de Microbiologia e Imunologia, Hospital das Clínicas, Faculdade de Medicina, Universidade de São Paulo, São Paulo, SP. [8]. Serviço de Transplante de Pulmão, Instituto do Coração, Hospital das Clínicas, Faculdade de Medicina, Universidade de São Paulo, São Paulo, SP.
\end{abstract}

\begin{abstract}
Epstein-Barr virus (EBV)-related post-transplant lymphoproliferative disease (PTLD) is one of the most serious complications associated with solid organ and hematopoietic stem cell transplantation. PTLD is most frequently seen with primary EBV infection post-transplant, a common scenario for pediatric solid organ recipients. Risk factors for infection or reactivation of EBV following solid organ transplant are stronger immunosuppressive therapy regimens, and being seronegative for receptor. For hematopoietic stem cell transplantation, the risk factors relate to the type of transplant, human leukocyte antigen disparity, the use of stronger immunosuppressants, T-cell depletion, and severe graft-versus-host disease. Mortality is high, and most frequent in patients who develop PTLD in the first six months post-transplant. The primary goal of this article is to provide an overview of the clinical manifestations, diagnosis, accepted therapies, and management of EBV infection in transplant recipients, and to suggest that the adoption of monitoring protocols could contribute to a reduction in related complications.
\end{abstract}

Keywords: Epstein-Barr virus. Lymphoproliferative disorders. Transplantation. Diagnosis. Combined modality therapy.

Epstein-Barr virus (EBV) is a deoxyribonucleic acid (DNA) virus of the herpes family that infects B-cells and the epithelial cells of the oropharynx. Infection results in different degrees of activation and proliferation of B-cells, and a latent infection is established within these cells. An intact immune system can control this infection, through either B-cell apoptosis, or cytotoxic T-cell activity. However, in the presence of post-transplant immunosuppression, immune control ceases to be effective and there is a risk of lymphoproliferative disease development ${ }^{1}$.

Although all cases of post-transplant lymphoproliferative disease (PTLD) are not caused by EBV, EBV-related PTLD is one of the main complications associated with relevant morbidity and mortality in solid organ transplant recipients. Its incidence is higher in children than in adults, and varies

\footnotetext{
Address to: $\mathrm{Dr}^{\mathrm{a}}$ Heloisa Helena de Sousa Marques. Instituto da Criança/HC/ FMSUP. Av. Dr Enéas de Carvalho Aguiar 647, 05403-000 São Paulo, SP, Brasil. Phone: 5511 9-9936-5276; Fax: 5511 2661-8503

e-mail: heloisa.marques@hc.fm.usp.br

Received 14 February 2014

Accepted 30 July 2014
}

depending on the transplanted organ: $33 \%$ for combined liverkidney transplantation, $20 \%$ for small intestine, $15 \%$ for heart, $10 \%$ for liver, $6.4 \%$ for lungs, and $1.2 \%$ for kidneys. The observed differences may be related to the amount of lymphoid tissue transplanted, and the level of immunosuppressive therapy required to prevent transplant rejection ${ }^{2-5}$. EBV-related PTLD occurs more frequently in children owing to primary infection, while its occurrence in adults is a result of either primary infection or reactivation ${ }^{6,7}$. Presentation can vary from polyclonal reactive hyperplasia of B-cells, to monoclonal or polyclonal lymphomas.

Analysis of records from a database of 200,000 solid organs transplantations, at 271 centers in 42 European countries, showed that the frequency of EBV-related PTLD is highest for heartlung transplantation $(42.7 \%)$, followed by the liver $(21.8 \%)$, heart (16\%), and kidney $(10.3 \%)^{1}$. Mortality due to EBV-related PTLD is also high, ranging from $25 \%$ to $48 \%$, and is more frequent in patients who develop PTLD in the first six months post-transplant ${ }^{8}$. The main risk factors are: I) having transplant receptors susceptible to EBV; II) being less than 5 years of age (risk decreases with age), III) being in the first 12 months post-transplant; and IV) a high level of immunosuppressive 
treatment, mainly through the administration of antithymocyte globulin (ATG) or muromonab-CD3 (Orthoclone OKT3).

For patients undergoing hematopoietic stem cell transplantation (HSCT), immunosuppressive therapy can lead to a mono- or poly-clonal proliferation of B-cells infected with EBV, resulting in the development of PTLD. The highest incidence of disease is in the first five months post-transplant, with reported levels ranging from 0.5 to $22 \%$ based on different studies. Additional risk factors that are also significant are the use of unrelated donor material and graft-versus-host disease (GVHD) $)^{9-11}$.

\section{CLINICAL SPECTRUM}

There are no pathognomonic signs for PTLD; thus, it is essential to maintain a high degree of clinical suspicion and surveillance in order to make an early diagnosis. EBV infection and/or PTLD should be considered if the following signs or symptoms are present: I) a persistent fever, alone, or in association with gastrointestinal manifestations (diarrhea, abdominal pain, intestinal bleeding, protein-losing enteropathy, and, more rarely, intestinal perforation/obstruction); II) lymphadenopathy; III) tonsil or adenoid hypertrophy; IV) mononucleosis-like syndrome; V) hepatomegaly or splenomegaly; VI) anemia, leukopenia, pancytopenia, or hemophagocytosis; VII) graft dysfunction; or VIII) other pulmonary or central nervous system-associated signs or symptoms ${ }^{5,12}$.

\section{DIAGNOSIS OF EBV-RELATED PTLD IN TRANSPLANT RECIPIENTS}

A number of analyses are recommended for effective diagnosis and monitoring of EBV infection. Virus capsid antigen immunoglobulin (IgG and IgM (anti-VCA), and Epstein Barr nuclear antigen (EBNA) serology of the transplant recipient are recommended pre-transplant to determine if they may be susceptible to primary infection, reactivation, or carry a latent infection ${ }^{9}$. In addition, polymerase chain reaction (PCR) monitoring of viral replication should be conducted immediately post-transplant and periodically throughout the following year, depending on the risk status of the case $\mathrm{e}^{13,14}$; there is evidence to support the efficacy of systematic PCR evaluation of EBV viral load in high-risk patients ${ }^{14}$.

Patients showing persistent viral replication, or those with initially high EBV levels, have a higher risk of progressing to PTLD. However, there are no precise protocols to determine the frequency of follow-up. Measurement of EBV load at the time of transplant, monthly for the first six months, and then every two months for the following six months has been suggested. In addition, weekly viral load measurements are recommended for the first six months for high-risk HSCT patients. Patients with two or more of the following risk factors are considered highrisk: susceptible, having an unrelated donor or human leukocyte antigens (HLA) disparity, or undergoing haploidentical transplantation, ATG therapy, or T-cell depletion ${ }^{9-11}$.

It is also important to mention that international standards have yet to be defined for EBV viral load measurement, this will be necessary to enhance inter-laboratory reliabilitys.

The term PTLD represents a spectrum of lymphoproliferative states that include benign conditions such as lymphoid hyperplasia, infectious mononucleosis-like disease, and malignancies, however, when not specified, PTLD generally refers to the neoplastic end of this spectrum. Neoplasia is defined as any two of the following three characteristics: I - destruction of the underlying lymph node architecture; II - monoclonality; and III - evidence of EBV infection in neoplastic cells ${ }^{15}$.

If PTLD is suspected a biopsy of the affected organ is recommended, with diagnosis based on World Health Organization (WHO) criteria. WHO PTLD classification includes four categories: I) early lesions; II) polymorphic PTLD; III) monomorphic PTLD, and IV) classical Hodgkin lymphoma-type PTLD ${ }^{16,17}$. Early lesions are characterized by a polyclonal lymphoid proliferation with B-, T- and plasma cells with phenotypic homogeneity. In polymorphic PTLD, lymphoid cells form destructive extranodal masses, tissue architecture is damaged, and there is a proliferation of monoclonal B-cells. Monomorphic PTLD often presents with $R A S$, $M y c$, and P53 mutations and, in some cases, an altered B-cell immunophenotype with low or minimal CD20 expression ${ }^{17-19}$.

Other examinations conducted to determine the extent of disease include bone marrow biopsy, lumbar puncture for cerebrospinal fluid (CSF) collection, and analysis besides radiological assessment. Chest and abdomen tomography and central nervous system (CNS) magnetic nuclear resonance can contribute to the diagnosis of PTLD in organs or systems located in the corresponding $\operatorname{areas}^{20}$, and, if a patient cannot receive a contrast for investigation of disease in the abdomen, magnetic nuclear resonance is a good alternative. Endoscopy and colonoscopy should be performed in patients with unexplained abdominal complaints and diarrhea following the exclusion of infection with other pathogens.

\section{PREVENTION OF PTLD}

Strategies for the prevention of EBV-related PTLD under investigation include immunoprophylaxis, chemoprophylaxis, and preemptive therapy. PCR analysis of peripheral blood for EBV viral load has been proven to be effective for early diagnosis of EBV-related PTLD, particularly for high-risk patients ${ }^{5}$. The detection of EBV DNA through quantitative real-time PCR (RTq-PCR) is currently considered the gold standard $^{5,21}$. The adoption of monitoring protocols by different services has reduced the incidence of this complication, as observed by Imadome K and others; it has also improved overall PTLD-related survival and reduced morbidity for both solid organ transplantation and $\mathrm{HSCT}^{2,5,22,23}$. The monitoring of EBV viral load could indicate when immunosuppressive therapy should be reduced and/or antiviral agents administered. However, further research is required in order to develop individualized monitoring programs specific to transplant type and risk level ${ }^{24}$.

\section{TREATMENT OF PTLD}

There is no consensus on PTLD treatment; however, the main therapeutic options are as follows:

- A reduction in immunosuppressive therapy should be considered as the first-line of treatment, and must be individualized to each patient. With this strategy response 
rates vary from $0 \%$ to $89 \%{ }^{3,21}$. However, it is often not possible for patients undergoing $\mathrm{HSCT}^{25,26}$.

- Although they are widely used, antiviral agents such as acyclovir and ganciclovir, alone, or in combination with immunoglobulins, have not been proven efficacious in the treatment of EBV-related PTLD 5 .

- Anti-B-cell and anti-CD20 (Rituximab) specific chimeric monoclonal antibody treatment has shown promising results. Some have suggested that these be administered following reduction of immunosuppressive therapy ${ }^{27}$. Descriptive studies have shown that early anti-CD20 treatment during HSCT conditioning in patients with B-cell lymphoma and severe aplastic anemia can prevent EBV reactivation with a low impact on immune reconstitution $^{15,28}$. In another study, a single dose of antiCD20 $\left(150 \mathrm{mg} / \mathrm{m}^{2}\right)$ was prescribed to 29 multi-visceral transplant recipients treated with ATG resulting in no cases of PTLD 6 months post-transplantation ${ }^{29}$.

- Rituximab at a dose of $375 \mathrm{mg} / \mathrm{m}^{2}$ weekly for four weeks is also recommended. However, IgG levels should be monitored at monthly intervals since hypogammaglobulinemia is an adverse event related to its use. In such cases, it can be replaced with intravenous Ig (IVIG) below $500 \mathrm{mg} / \mathrm{dL}^{30}$.

- In patients with persistent or progressive disease, in spite of a reduction in immunosuppressive therapy, and evidence of graft rejection, or patients with an adverse reaction to Rituximab, treatment with low doses of cyclophosphamide and corticosteroids is indicated. This treatment should be guided by an onco-hematology group, which should be involved since clinical suspicion for diagnostic orientation, management definition and the follow-up of patients with PTLD ${ }^{5,31}$.

- Radiotherapy or surgical resection are usually indicated in cases of localized disease and should be considered for patients with CNS PTLD ${ }^{32}$.

- Selective restoration of impaired immune function through the adoptive transfer of EBV-specific cytotoxic T-cells has recently been used as pre-emptive treatment for EBV-related PTLD in HSCT patients ${ }^{17,33-38}$. Donorderived T-cells are stimulated, expanded over 3 to 4 weeks, and transferred to patients ${ }^{17}$. EBV-related PTLD after haploidentical HSCT has been successfully treated using this method using cells from the haploidentical donor $^{35}$. In addition, a bank of EBV-cytotoxic T-cells from healthy donors has been used as an alternative source for allogeneic cord blood HSCT patients with adverse reactions to rituximab, for whom donors are not usually available ${ }^{38}$.

In conclusion, PTLD is one of the most severe complications associated with organ transplantation. Early diagnosis requires a high level of clinical suspicion and vigilance. Patient outcomes can be improved through EBV viral load surveillance and the adoption of adequate preventive and therapeutic strategies. The optimization of monitoring, prevention, and treatment of EBVPTLD is an important area for further investigation.

\section{CONFLICT OF INTEREST}

The authors declare that there is no conflict of interest.

\section{REFERENCES}

1. Opelz G, Döhler B. Lymphomas after solid organ transplantation: a collaborative transplant study report. Am J Transplant 2003; 4:222-230.

2. Gallego S, Llort A, Gros L, Sanchez de Toledo Jr J, Bueno J, Moreno A, et al. Post-transplant lymphoproliferative disorders in children: the role of chemotherapy in the era of rituximab. Pediatr Transplant 2010; 14:61-66.

3. Holmes RD, Sokol RJ. Epstein-Barr virus and post-transplant lymphoproliferative disease. Pediatr Transplant 2002; 6:456-464.

4. Cockfield SM. Identifying the patient at risk for post-transplant lymphoproliferative disorder. Transpl Infect Dis 2001; 3:70-78.

5. Green M, Michaels MG. Epstein-Barr virus infection and posttransplant lymphoproliferative disorder. Am J Transplant 2013; 13 (supl III):41-54.

6. Ho M, Jaffe R, Miller G, Breinig MK, Dummer JS, Makowka L, et al. The frequency of Epstein-Barr virus infection and associated lymphoproliferative syndrome after transplantation and its manifestations in children. Transplantation 1988; 45:719-727.

7. Shapiro R, Nalesnik M, McCauley J, Fedorek S, Jordan ML, Scantlebury VP, et al. Posttransplant lymphoproliferative disorders in adult and pediatric renal transplant patients receiving tacrolimus-based immunosuppression. Transplantation 1999; 68:1851-1854.

8. Collins MH, Montone KT, Leahey AM, Hodinka RL, Salhany KE, Kramer DL, et al. Post-transplant lymphoproliferative disease in children. Pediatr Transplant 2001; 5:250-257.

9. Gerritsen EJ, Stam ED, Hermans J, van den BH, Haraldsson A, van Tol MJ, et al. Risk factors for developing EBV-related B cell lymphoproliferative disorders (BLPD) after non-HLA-identical BMT in children. Bone Marrow Transplant 1996; 18:377-382.

10. Curtis RE, Travis LB, Rowlings PA, Socie G, Kingma DW, Banks PM, et al. Risk of lymphoproliferative disorders after bone marrow transplantation: a multi-institutional study. Blood 1999; 94:2208-2216.

11. Sundin M, Le BK, Ringden O, Barkholt L, Omazic B, Lergin C, et al. The role of HLA mismatch, splenectomy and recipient Epstein-Barr virus seronegativity as risk factors in post-transplant lymphoproliferative disorder following allogeneic hematopoietic stem cell transplantation. Haematologica 2006; 91:1059-1067.

12. Gross TG, Savoldo B, Punnett A. Posttransplant lymphoproliferative diseases. Pediatr Clin North Am 2010; 57:481-503.

13. Stevens SJ, Verschuuren EA, Verkuujlen SA, Van Den Brule AJ, Meijer CJ, Middeldorp JM. Role of Epstein-Barr virus DNA load monitoring in prevention and early detection of post-transplant lymphoproliferative disease. Leuk Lymphoma 2002; 43:831-840.

14. Gavaldà J, Vidal E, Lumbreras C. Infection prevention in solid organ transplantation. Enferm Infecc Microbiol Clin 2012; 30 (supl II):27-33.

15. Loren AW, Tsai. Post-transplant lymphoproliferative disorder. Clin Chest Med 2005; 26:631-645.

16. Swerdlow SH, Campo E, Harris NL, Jaffe ES, Pileri SA, Stein H, et al. WHO Classification of Tumors of Haematopoietic and Lymphoid Tissues. $4^{\text {th }}$ ed. Lyon, France: International Agency for Research on Cancer; 2008.

17. Rashe L, Kapp M, Einsele H, Mielke S. EBV-induced post transplant lymphoproliferative disorders: a persisting challenge in allogeneic hematopoetic SCT. Bone Marrow Transplant 2014; 49:163-167.

18. Comoli P, Basso S, Zecca M, Pagliara D, Baldanti F, Bernardo ME, et al. Preemptive herapy of EBV-related lymphoproliferative disease after pediatric haploidentical stem cell transplantation. Am J Transplant 2007; 7:1648-1655. 
19. Muramatsu H, Takahashi Y, Shimoyama Y, Doisaki S, Nishio N, Ito Y, et al. CD20-negative Epstein-Barr virus-associated post-transplant lymphoproliferative disease refractory to rituximab in a patient with severe aplastic anemia. Int J Hematol 2011; 93:779-781.

20. Borhani AA, Hosseinzadeh K, Almusa O, Furlan A, Nalesnik M. Image of Posttransplantation lymphoproliferative disorder after solid organ transplantation. Radiographics 2009; 29:981-1002.

21. Carratalà J, Montejo M, Pérez-Romero P. Infections caused by herpes viruses other than cytomegalovirus in solid organ transplant recipients. Enferm Infecc Microbiol Clin 2012; 30: (supl II):63-69.

22. Schönberger S, Meisel R, Adams O, Pufal Y, Laws HJ, Enczmann J, et al. Prospective, comprehensive, and effective viral monitoring in children undergoing allogeneic hematopoietic stem cell transplantation. Biol Blood Marrow Transplant 2010; 16:1428-1435.

23. Imadome K, Fukuda A, Kawano F, Imai Y, Ichikawa S, Mochizuki M, et al. Effective control of Epstein-Barr virus infection following pediatric liver transplantation by monitoring of viral DNA load and lymphocyte surface markers. Pediatr Transplant 2012; 16:748-757.

24. Gulley ML, Tang W. Using Epstein-Barr Viral Load Assays To Diagnose, Monitor, and Prevent Posttransplant Lymphoproliferative Disorder. Clin Microbiol Rev 2010; 23:350-366.

25. Heslop HE. How I treat EBV lymphoproliferation. Blood 2009; 114:4002-4008.

26. Reddy N, Rezvani K, Barrett AJ, Savani BN. Strategies to prevent EBV reactivation and posttransplant lymphoproliferative disorders (PTLD) after allogeneic stem cell transplantation in high-risk patients. Biol Blood Marrow Transplant 2011; 17:591-597.

27. Lee JJ, Lam MS, Rosenberg A. Role of chemotherapy and rituximab for treatment of posttransplant lymphoproliferative disorder in solid organ transplantation. Ann Pharmacother 2007; 41:1648-1659.

28. Savani BN, Pohlmann PR, Jagasia M, Chimratanalab W, Kassim A, Engelhardt B, et al. Does peritransplantation use of rituximab reduce the risk of EBV reactivation and PTLPD? Blood 2009; 113:6263-6264.

29. Vianna RM, Mangus RS, Fridell JA, Weigman S, Kazimi M, Tector J. Induction immunosuppression with thymoglobulin and rituximab in intestinal and multivisceral transplantation. Transplantation 2008; 85:1290-1293.
30. EBV Work Group, Cincinnati Children's Hospital Medical Center. Evidence-based clinical care guideline for Management of EBVAssociated Post-Transplant Lymphoproliferative Disease in Solid Organ Transplant. Guideline 18, pages 1-18, June, 2011. Available at: http:// www.cincinnatichildrens.org/svc/alpha/h/health-policy/guidelines.htm/.

31. Bacigalupo A, Locatelli F, Lanino E, Prete A, Locatelli F, Locasciulli A, et al. Fludarabine, Cyclophosphamide with or without low dose TBI for alternative donor transplants in acquired aplastic anemia (SAA): a report from the EBMT-SAA Working Party. Biol Blood Marrow Transplant 2009; 15:5.

32. Cavaliere R, Petroni G, Lopes MB, Schiff D. Primary central nervous system post-transplantation lymphoproliferative disorder: An International Primary Central Nervous System Lymphoma Collaborative Group Report. Cancer 2010; 116:863-870.

33. Rooney CM, Smith CA, Ng CY, Loftin SK, Sixbey JW, Gan Y, et al. Infusion of cytotoxic $\mathrm{T}$ cells for the prevention and treatment of EpsteinBarr virus-induced lymphoma in allogeneic transplant recipients. Blood 1998; 92:1549-1555.

34. Heslop HE, Slobod KS, Pule MA, Hale GA, Rousseau A, Smith CA, et al. Long-term outcome of EBV-specific T-cell infusions to prevent or treat EBV-related lymphoproliferative disease in transplant recipients. Blood 2010; 115:925-935.

35. Uhlin M, Okas M, Gertow J, Uzunel M, Brismar TB, Mattsson J. A novel haplo-identical adoptive CTL therapy as a treatment for EBV-associated lymphoma after stem cell transplantation. Cancer Immunol Immunother 2010; 59:473-477.

36. Dominietto A, Tedone E, Soracco M, Bruno B, Raiola AM, Van Lint MT, et al. In vivo B-cell depletion with rituximab for alternative donor hemopoietic SCT. Bone Marrow Transplantation 2012; 47:101-106.

37. Coppoletta S, Tedone E, Galano B, Soracco M, Raiola AM, Lamparelli T, et al. Rituximab treatment for Epstein-Barr virus DNAemia after alternative-donor hematopoietic stem cell transplantation. Biol Blood Marrow Transplant 2011; 17:901-907.

38. Barker JN, Doubrovina E, Sauter C, Jaroscak JJ, Perales MA, Doubrovin M, et al. Successful treatment of EBV-associated posttransplantation lymphoma after cord blood transplantation using third-party EBVspecific cytotoxic T lymphocytes. Blood 2010; 116:5045-5049. 